Pengaruh Likuiditas, Solvabilitas, dan Profitabilitas untuk Mengetahui Kondisi Keuangan yang Berdampak terhadap Prediksi Financial Distress pada Pt Bakrie \& Brothers, Tbk dan Anak Perusahaan

\title{
PENGARUH LIKUIDITAS, SOLVABILITAS, DAN PROFITABILITAS UNTUK \\ MENGETAHUI KONDISI KEUANGAN YANG BERDAMPAK TERHADAP \\ PREDIKSI FINANCIAL DISTRESS PADA PT BAKRIE \& BROTHERS, TBK DAN \\ ANAK PERUSAHAAN
}

\author{
Patar Simamora \\ Dosen Tetap Fakultas Ekonomi \\ Universitas Pakuan \\ Muhamad Haerudin \\ Mahasiswa Fakultas Ekonomi \\ Universitas Pakuan
}

\begin{abstract}
Financial distress is a condition experienced by the company caused by several factors, namely liquidity, solvency, and profitability. This study was conducted to determine the effect of liquidity, solvency, and profitability of the financial distress prediction in PT.Bakrie \& Brothers, Tbk and subsidiaries as a result of inability of the company to pay off debt and suffered losses several times in the period 2003-2012. The results showed liquidity, solvency, and profitability in poor condition. This condition is reinforced by the results of the analysis by using EVA, MVA, and Z"-Scores methods. Hypothesis testing using the F test shows $F$ count > F table $(8,583>2,866)$ means liqudity, solvency, and profitability simultaneously affect the prediction of finacial distress. While testing the hypothesis using the $t$ test showed the value of the current ratio $(2,359>2,028)$ and debt to total assets ratio $(4,730>2,028)$ where $t$ count $>$ t table which means the effect on the interest covarege ratio, meanwhile for the return on invesment $-t$ count $<-t$ table $(-1,150<-2,028)$, which means affect too the interest covarage ratio.
\end{abstract}

Keywords : Liquidty, Solvency, Profitability, Financial Distress, Current Ratio, Debt To Total Assets Ratio, Return On Invesment, Interest Covarage Ratio.

\section{Pendahuluan}

Persaingan perusahaan disaat ini sudah semakin ketat dan sengit. Di kondisi seperti ini perusahaan dituntut untuk tetap konsisten menjaga kestabilan kinerja, mengembangkan inovasi, dan memperluas cakupan usaha sehingga dapat terus bertahan dan mencapai tujuan yang diinginkan perusahaan. Kerugian ini bisa dilihat dari penjualan dan laba perusahaan yang semakin menurun serta jumlah hutang yang semakin besar. Kondisi seperti ini 
Pengaruh Likuiditas, Solvabilitas, dan Profitabilitas untuk Mengetahui Kondisi Keuangan yang

Berdampak terhadap Prediksi Financial Distress pada Pt Bakrie \& Brothers, Tbk dan Anak Perusahaan

mengakibatkan perusahaan mengalami kondisi kesulitan keuangan atau biasa disebut financial distress ( Berk dan DeMarzo, 2007;491)

Financial distress atau kesulitan keuangan adalah suatu kondisi dimana sebuah perusahaan mengalami kesulitan untuk membayar kewajiban-kewajiban nya akibat kegagalan dalam mengelola dan menjaga kestabilan kinerja keuangan yang menyebabkan perusahaan mengalami kerugian. Kondisi kesulitan keuangan (financial distress) yang dialami sebuah perusahaan dapat dilihat dari laporan keungan perusahaan tersebut. Mulai dari laporan laba rugi, neraca, arus kas, perubahan modal dan lain-lain.

Objek yang digunakan dalam penilitian ini adalah PT. Bakrie \& Brothers, Tbk dan anak perusahaan. Anak perusahaan Bakrie yang digunakan yaitu PT. Energi Mega Persada, Tbk, PT. Bakrie Telecom, Tbk dan PT. Bakrie Sumatera Plantation, Tbk. Alasan dipilihanya ketiga anak perusahaan tersebut adalah dalam kurun waktu sepuluh tahun terakhir punya andil yang sangat besar dalam keterpurukan yang dialami PT. Bakrie \& Brothers, Tbk. Dengan mengacu pada laporan keuangan PT. Bakrie \& Brothers, Tbk beberapa tahun ke belakang terdapat beberapa aspek yang dapat dikaitkan dengan kondisi kesulitan keuangan yang dialami perusahaan. PT. Bakrie \& Brothers, Tbk mulai mengalami keterpurukan setelah terlilit hutang yang sangat besar yaitu Rp21,4 Trilyun akibat beberapa faktor. Faktor yang menyebabkan terpuruknya PT. Bakrie \& Brothers, Tbk diantaranya adalah adanya kasus Lapindo, terkena imbas krisis Eropa, dan gagal bayar terhadap hutang credit issue. Selain itu, hilangnya kepercayaan masyarakat maupun para investor terhadap kinerja grup Bakrie mengakibatkan harga saham PT. Bakrie \& Brothers, Tbk tak menentu hingga terjun bebas di awal tahun 2009 sampai saat ini berada di level terendah harga saham yaitu Rp50 perlembar saham. Faktor-faktor tersebut tentunya tidak luput akibat dari pengaruh tiga anak perusahaan PT. Bakrie \& Brothers, Tbk yaitu PT. Energi Mega Persada, Tbk, PT. Bakrie Telecom, Tbk dan PT. Bakrie Sumatera Plantation, Tbk. Keadaan ini membuat PT. Bakrie \& Brothers, Tbk dan anak perusahaan dipredisikan sedang mengalami kondisi kesulitan keuangan (financial distress).

Oleh karena itu tujuan dari penilitian ini adalah sebagai berikut : 1) Untuk menganilisis tingkat likuiditas PT. Bakrie \& Brothers, Tbk dan anak perusahaan; 2) Untuk menganilisis tingkat solvabilitas PT. Bakrie \& Brothers, Tbk dan anak perusahaan; 3) Untuk menganalisis tingkat profitabilitas PT. Bakrie \& Brothers, Tbk dan anak perusahaan; 4) Untuk mengetahui kondisi financial distress yang dialami PT. Bakrie \& Brothers, Tbk dan anak perusahaan; 5) untuk mengetahui pengaruh likuiditas, solvabilitas, dan profitabilitas terhadap prediksi 
Pengaruh Likuiditas, Solvabilitas, dan Profitabilitas untuk Mengetahui Kondisi Keuangan yang Berdampak terhadap Prediksi Financial Distress pada Pt Bakrie \& Brothers, Tbk dan Anak Perusahaan

financial distress PT. Bakrie \& Brothers, Tbk dan anak perusahaan. a) untuk membuktikan bahwa current ratio berpengaruh positif terhadap interest covarage ratio; b) untuk membuktikan bahwa debt to total assets ratio berpengaruh postif terhadap interest covarage ratio; c) untuk membuktikan bahwa return on investment berpengaruh negatif terhadap interest covarage ratio.

\section{Metode penelitian}

Metode penilitian yang digunakan oleh penulis untuk skripsi ini yaitu 1) Metode Desain Penelitian, merupakan rancangan atau perincian tahapan untuk melakukan suatu pengamatan, pemeriksaan, dan mempelajari berbagai faktor yang berhubungan sehingga dapat diolah dan diintrepretasikan dalam bentuk informasi yang tepat, akurat dan dapat dipertanggungjawabkan. Dengan memenuhi beberapa syarat yang harus dipenuhi yaitu sistematis, terencana, dan ilmiah. Unsur yang terdapat dalam desain penelitian anatara lain jenis penelitian, metodologi penelitian, dan teknik penelitian; 2) Operasionalisasi Variabel, penelitian ini dikelompokan menjadi variabel bebas (independent variabel) adalah variabel yang menjadi sebab atau berubah/memengaruhi suatu variabel lain dan variabel terikat (depedent variabel) adalah variabel yang dipengaruhi atai menjadi akibat, karena adanya variabel lain; 3) Metode Penarikan Sampel, dengan menggunakan teknik purposive sampling. Dimana teknik purposive sampling digunakan berdasarkan ciri-ciri atau tanda yang memiliki kaitan erat dengan ciri atau tanda populasi yang telah diketahui sebelumya; 4) Prosedur Pengumpulan Data, dalam penelitian ini, penulis menggunakan dua metode pengumpulan metode pengumpulan data yaitu metode studi pustaka dan metode dokumentasi; 5) Metode Analisis data, Unit analisis yang digunakan adalah analisis ratio, pengujian asumsi klasik, regresi linier berganda, dan pengujian hipotesis.

\section{Hasil dan Pembahasan}

III.1. Tingkat Likuiditas PT. Bakrie \& Brothers, Tbk dan Anak Perusahaan

Dengan menggunakan rasio lancar (current ratio). Kondisi likuiditas PT. Energi Mega Persada, Tbk, PT. Bakrie Telecom, Tbk dan PT. Bakrie Sumatera Plantation, Tbk periode 2003-2012 tidak baik dan sangat mengkhawatirkan. Hal ini dikarenakan angka ratio likuditias yang belum berada pada level baik dan aman serta angka yang turun secara drastis dalam beberapa tahun terakhir. Selain itu PT. Bakrie \& Brothers, Tbk dan anak perusahaannya 
Pengaruh Likuiditas, Solvabilitas, dan Profitabilitas untuk Mengetahui Kondisi Keuangan yang

Berdampak terhadap Prediksi Financial Distress pada Pt Bakrie \& Brothers, Tbk dan Anak Perusahaan

memiliki rata-rata rasio likuiditas yang rendah dan berada pada level tidak aman akibat banyaknya jumlah angka likuiditas yang berada jauh di bawah rata-rata.

III.2. Tingkat Solvabilitas PT. Bakrie \& Brothers, Tbk dan Anak Perusahaan.

Dengan menggunakan rasio hutang (debt to total assets ratio), Kondisi solvatabilitas PT. Energi Mega Persada, Tbk, PT. Bakrie Telecom, Tbk dan PT. Bakrie Sumatera Plantation, Tbk periode 2003-2012 masih cukup baik namun harus diwaspadai. Hal ini dikarenakan kenaikan total aset yang dimiliki perusahaan berbanding lurus dengan kenaikan total kewajiban yang harus dipenuhi perusahaan. hal ini terlihat dari kenaikan yang terjadi setiap tahun pada kondisi solvabilitas anak perusahaan PT. Bakrie \& Brothers, Tbk. Sementara dari segi rata-rata solvabilitas dapat dikatakan cenderung kurang konsisten. Masalah tersebut tentunya berakibat pada fluktuasi kondisi solvabilitas PT. Bakrie \& Brothers, Tbk.

III.3. Tingkat Profitabilitas PT. Bakrie \& Brothers, Tbk Dan Anak Perusahaannya

Dengan menggunakan rasio return on invesment (ROI), kondisi profitabilitas PT. Energi Mega Persada, Tbk, PT. Bakrie Telecom, Tbk dan PT. Bakrie Sumatera Plantation, Tbk periode 2003-2012 tidak baik. dalam kurun waktu sepuluh tahun terakhir perusahaan mengalami kerugian bahkan lebih besar dari satu kali. Kerugian yang diderita juga dalam jumlah yang besar. Hal ini menandakan bahwa perusahaan tidak dapat mengoptimalkan penjualan dan pendapatan yang diperolehnya. Selain itu ketiga anak persahaan PT. Bakrie \& Brothers, Tbk juga mencatatkan angka negatif rata-rata profitabilitas perusahaan. hal ini ternyata berdampak sangat besar bagi PT. Bakrie \& Brothers, Tbk. Akibat kerugian yang diderita anak perusahaannya, kerugian ini terakumulasi sehingga perusahaan mengalami kerugian selama tiga tahun berturut-turut bahkan dalam jumlah yang terbesar sepanjang sejarah perusahaan.

III.4. Analisi EVA, MVA, dan Z"-Score Untuk Mengetahui Kondisi Keungan PT. Bakrie \& Brothers, Tbk dan Anak Perusahaannya.

Untuk lebih mengetahui kondisi keuangan dan memperkuat prediksi financial distress yang dialami PT. Bakrie \& Brothers, Tbk dan anak perusahaannya yaitu PT. Energi Mega Persada, Tbk, PT. Bakrie Telecom, Tbk dan PT. Bakrie Sumatera Plantation, Tbk maka dalam penelitian ini ditambahkan analisis EVA (Economic Value Added), MVA (Market Value Added), dam analisi Z"'-score.

1. Analisis EVA (Economic Value Added) Pada PT. Bakrie \& Brothers, Tbk dan Anak Perusahaan. 
Pengaruh Likuiditas, Solvabilitas, dan Profitabilitas untuk Mengetahui Kondisi Keuangan yang Berdampak terhadap Prediksi Financial Distress pada Pt Bakrie \& Brothers, Tbk dan Anak Perusahaan

Kondisi nilai EVA yang dialami ketiga anak perusahaan tentunya sangat berdampak pada nilai EVA yang dihasilkan PT. Bakrie \& Brothers, Tbk selama periode 20032012 nilai EVA PT. Bakrie \& Brothers, Tbk berada pada area negatif atau dibawah nol sebanayak tujuh kali. Kondisi tersebut terjadi pada tahun 2003-2005, 2008, dan 2010-2012. Kondisi terburuk terjadi pada tahun 2010. sehingga dapat dismpulkan bahwa kondisi keuangan PT. Bakrie \& Brothers, Tbk dan anak perusahaannya yaitu PT. Energi Mega Persada, Tbk, PT. Bakrie Telecom, Tbk dan PT. Bakrie Sumatera Plantation, Tbk berada pada level yang tidak baik. ini didasari dari seringnya perusahaan memperoleh nilai EVA $<0$ dalam kurun waktu sepuluh tahun.

2. Analisis MVA (Market Value Added) Pada PT. PT. Bakrie \& Brothers, Tbk dan Anak Perusahaannya.

Hasil analisis MVA dapat disimpulkan bahwa kondisi keuangan PT. Bakrie \& Brothers, Tbk dan anak perusahaannya yaitu PT. Energi Mega Persada, Tbk, PT. Bakrie Telecom, Tbk dan PT. Bakrie Sumatera Plantation, Tbk tidak baik. hal ini dapat terlihat dari nilai MVA yang negatif yang didapat perusahaan. kondisi ini terjadi akibat jumlah ekuitas saham yang dikeluarkan perusahaan yang berasal dari investor tidak disertai dengan harga saham yang dibukukan perusahaan. Harga saham PT. Bakrie \& Brothers, Tbk dan ketiga anak perusahaannya masih relatif kecil bahkan cenderung menurun di setiap tahunnya dan anjlok pada akhir tahun 2012. PT. Bakrie \& Brothers, Tbk dan ketiga anak perusahaannya mencatatkan nilai saham masingmasing 50, 82, 50, dan 93. Nilai tersebut dapat dikategorikan sebagai nilai terendah pada indeks harga saham di BEI (Bursa Efek Indonesia) sehingga menyebabkan PT. Bakrie \& Brothers, Tbk dan anak perusahaannya yaitu PT. Energi Mega Persada, Tbk, PT. Bakrie Telecom, Tbk dan PT. Bakrie Sumatera Plantation, Tbk mengalami kesulitan keuangan.

3. Analisis Model Z"-Score Pada PT. Bakrie \& Brothers, Tbk dan Anak Perusahaannya. Kondisi yang dialami ketiga anak perusahaan membuat kondisi PT. Bakrie \& Brothers, Tbk dan anak perusahaannya yaitu PT. Energi Mega Persada, Tbk, PT. Bakrie Telecom, Tbk dan PT. Bakrie Sumatera Plantation, Tbk berada pada level yang kurang baik. Hal ini dapat terlihat dari seringnya PT. Bakrie \& Brothers, Tbk dan anak perusahaan berada pada level bangkrut dan grey area berdasarkan model Z"Score yang dipakai dalam mendukung penilitian ini.

III.5. Prediksi Financial Distress Pt. Bakrie \& Brothers, Tbk Dan Anak Perusahaan. 
Dengan menggunakan interest covarage ratio (ICR), dapat disimpulkan bahwa PT. Energi Mega Persada, Tbk, PT. Bakrie Telecom, Tbk dan PT. Bakrie Sumatera Plantation, Tbk berada dalam kondisi kesulitan keuangan. Laba operasional yang berfluktuasi dan kurang optimal ditambah dengan jumlah beban bunga yang semakin meningkat di setiap tahunnya serta angka prediksi yang sering berada dibawah rata-ta membuat anak perusahaan PT. Bakrie \& Brothers, Tbk harus membuat keputusan agar perusahaan bisa tetap bertahan.

Kondisi buruk yang dialami PT. Energi Mega Persada, Tbk, PT. Bakrie Telecom, Tbk dan PT. Bakrie Sumatera Plantation, Tbk tentunya berakibat buruk bagi PT. Bakrie \& Brothers, Tbk prediksi financial distress semakin menguat akibat penurunan drastis yang terjadi dalam tiga tahun berturut-turut yaitu pada tahun 2008-2011. Penurunan ini tentunya tidak luput dari kondisi financial distress yang dialami anak perusahaan.

III.6. Pengaruh Likuiditas, Solvabilitas, dan Profitabilitas Terhadap Prediksi Financial Distress Pada PT. Bakrie \& Brothers, Tbk dan Anak Perusahaan.

Untuk mengetahui pengaruh likuiditas, solvabilitas, dan profitabilitas terhadap prediksi financial dalam penelitian ini digunakan alat analisis yaitu regresi linier berganda. Untuk mendapatkan model regresi yang baik dan benar maka perlu dilakukan uji kelayakan model regresi yaitu uji asumsi klasik yang didalamnya terdapat empat macam uji.

1. Uji Asumsi Klasik

a. Uji Normalitas

Uji normalitas pada model regresi digunakan untuk menguji apakah nilai residual yang dihasilkan dari regresi terdistribusi secara normal atau tidak. Salah satu metode yang dipakai dalam uji normalitas adalah dengan menggunakan metode uji One Sample Kolmogorov Smirnov.

b. Uji Multikolinearitas

Salah satu metode uji multikolinearitas yaitu dengan melihat nilai Tolerance dan Inflation Factor (VIF) pada model regresi. Untuk mengetahui suatu model regresi bebas dari multikolinearitas, yaitu mem[unyai nilai VIF (Variance Inflation Factor) kurang dari 10 dan mempunyai angka tolerance lebih dari 0,1.

c. Uji Heteroskedastisitas

Salah satu metode yang digunakan adalah metode uji Glejser. Jika nilai signifikansi antara variabel independen dengan absolut residual lebih dari 0,05 maka tidak terjadi heteroskdastisitas.

d. Uji Autokorelasi 
Pengaruh Likuiditas, Solvabilitas, dan Profitabilitas untuk Mengetahui Kondisi Keuangan yang Berdampak terhadap Prediksi Financial Distress pada Pt Bakrie \& Brothers, Tbk dan Anak Perusahaan

Metode pengujian menggunakan uji Durbin- Watson (DW test). Pengambilan keputusan pada uji Durbin- Watson adalah sebagai berikut :

a) DU < DW < 4-DU maka Ho diterima, artinya tidak terjadi autokorelasi.

b) DW < DL atau DW > 4-DL maka Ho ditolak, artinya terjadi autokorelasi.

c) DL $<$ DW $<$ DU atau 4-DU $<$ DW $<$ 4-DL, artinya tidak ada kepastian atau kesimpulan yang pasti.

2. Uji Regresi Linier Berganda

Setelah uji asumsi klasik terpenuhi, yaitu residual terdistribusi normal, tidak adanya multikolinearitas, tidak adanya heteroskedastisitas, dan tidak adanya autokorelasi pada model regresi maka diperoleh persamaan regresi linier berganda dengan interest covarage ratio sebagai dependen. Hasil nilai korelasi berganda (R), koefisien determinasi (R Square), Koefisien determinasi yang disesuaikan (Adjusted R Square), dan ukuran kesalahan prediksi (Std. Error ff the Estimate)

\section{SIMPULAN}

1. Berdasarkan perhitungan tingkat likuiditas periode 2003-2012 PT. Bakrie \& Brothers, Tbk dan anak perusahaannya yaitu PT. Energi Mega Persada, Tbk, PT. Bakrie Telecom, Tbk dan PT. Bakrie Sumatera Plantation, Tbk diprediksi sedang mengalami kesulitan keuangan (financial distress). Dalam kurun waktu sepuluh tahun terakhir perusahaan tidak mampu mempertahankan konsistensi likuiditas perusahaannya. Dengan demikian hipotesis yang menyatakan semakin rendah likuiditas perusahaan maka semakin tinggi profitabilitas PT. Bakrie \& Brothers, Tbk dan anak perusahaan mengalami financial distress dapat diterima.

2. Berdasarkan perhitungan tingkat solvabilitas PT. Bakrie \& Brothers, Tbk dan anak perusahaannya yaitu PT. Energi Mega Persada, Tbk, PT. Bakrie Telecom, Tbk dan PT. Bakrie Sumatera Plantation, Tbk periode 2003-2012 terdapat indikasi yang mengarah pada kesulitan keuangan. Hal ini dapat terlihat dari kondisi solvabilitas perusahaan yang masih cukup baik namun harus diwaspai akibat kenaikan yang terus terjadi di setiap tahunnya.

3. Berdasarkan perhitungan tingkat profitabilitas periode 2003-2012 PT. Bakrie \& Brothers, Tbk dan anak perusahaannya yaitu PT. Energi Mega Persada, Tbk, PT. Bakrie Telecom, Tbk dan PT. Bakrie Sumatera Plantation, Tbk diprediksi sedang mengalami kesulitan keuangan (financial distress). Hal ini dapat terlihat dari kondisi kerugian yang 
Pengaruh Likuiditas, Solvabilitas, dan Profitabilitas untuk Mengetahui Kondisi Keuangan yang

Berdampak terhadap Prediksi Financial Distress pada Pt Bakrie \& Brothers, Tbk dan Anak Perusahaan

dialami baik oleh PT. Bakrie \& Brothers, Tbk dan ketiga anak perusahaannya. Dengan demikian hipotesis yang menyatakan semakin rendah tingkat profitabilitas perusahaan maka semakin tinggi profitabilitas PT. Bakrie \& Brothers, Tbk dan anak perusahaan mengalami financial distress dapat diterima.

4. Berdasarkan perhitungan prediksi financial distress pada periode 2003-2012 dapat disimpulkan PT. Bakrie \& Brothers, Tbk dan anak perusahaannya yaitu PT. Energi Mega Persada, Tbk, PT. Bakrie Telecom, Tbk dan PT. Bakrie Sumatera Plantation, Tbk diprediksi sedang mengalami kesulitan keuangan (financial distress). Hal ini dapat terlihat dari angka prediksi yang yang berada pada level rendah dan terus menurun bahkan negatif dalam kurun waktu sepuluh tahun terakhir. Dengan demikian hipotesis yang menyatakan bahwa PT. Bakrie \& Brothers, Tbk dan anak perusahaan mengalami financial distress dapat diterima.

5. Dari pengujian statistik yang dilakukan dengan melakukan uji pengaruh (regresi) dapat disimpulkan bahwa secara simultan atau keseluruhan variabel indenpen yaiutu likuiditas, solvabilitias, dan profitabilitas seacara bersama-sama (simultan) berpengaruh terhadap variabel dependen yaitu prediksi financial distress. Sementara secara parsial pengaruh current ratio, debt to total assets ratio, dan return on investment dapat disimpulkan sebagai berikut.

a. Hasil uji t statistik dengan menggunakan software Statistical Product and Service Solution (SPSS) memperlihatkan nilai $\mathrm{t}$ hitung lebih besar dibandingkan nilai $\mathrm{t}$ tabel. Dengan demikian hipotesis yang menyatakan current ratio memiliki pengaruh positif terhadap interest covarage ratio pada PT. Bakrie \& Brothers, Tbk dan anak perusahaan mengalami financial distress dapat diterima.

b. Hasil uji t statistik dengan menggunakan software Statistical Product and Service Solution (SPSS) memperlihatkan nilai $\mathrm{t}$ hitung lebih besar dibandingkan nilai $\mathrm{t}$ tabel. Dengan demikian hipotesis yang menyatakan debt to total assets memiliki pengaruh positif terhadap interest covarage ratio pada PT. Bakrie \& Brothers, Tbk dan anak perusahaan mengalami financial distress dapat diterima.

c. Hasil uji t statistik dengan menggunakan software Statistical Product and Service Solution (SPSS) memperlihatkan nilai t hitung lebih kecil dibandingkan nilai $\mathrm{t}$ tabel. Dengan demikian hipotesis yang menyatakan return on investment memiliki pengaruh negatif terhadap interest covarage ratio pada PT. Bakrie \& Brothers, Tbk dan anak perusahaan mengalami financial distress dapat diterima. 


\section{DAFTAR PUSTAKA}

Agus Sartono. 2008. Manajemen Keuangan : Teori dan Aplikasi. Edisi Keempat, BPFE, Yogyakarta.

Atika, Darminto, dan Siti Ragil Handayani. 2011. Pengaruh Beberapa Rasio Keuangan Terhadap Prediksi Kondisi Financial Distress (Studi Pada Perusahaan Tekstil dan Garmen yang Terdaftar Di Bursa Efek Indonesia Periode 2008-2011). Fakultas Ilmu Administrasi Universitas Brawijaya, Malang.

Chalendra Prasetyo Agusti. 2013. Analisis Faktor Yang Mempengaruhi Kemungkinan Terjadinya Financial Distress. Fakultas Ekonomika dan Bisnis Universitas Diponegoro, Semarang.

Luciana Spica Almilia, Kristijadi. 2003. “Analisis Rasio Keungan Untuk Memprediksi Kondisi Financial Distress Perusahaan Manufaktur yang Terdaftar di Bursa Efek Jakarta”. JAAI, Vol.7, No.2.

Mohammad Farhan Qudratullah.2013. Analisis Regresi Terapan: Teori, Contoh Kasus, dan Aplikasi dengan SPSS. ANDI, Yogyakarta. 